\title{
The Impact of Social Media Usage on Employee and Organization Performance: A Study on Social Media Tools Used by an IT Multinational in Malaysia
}

\author{
Grace Shalini A/P Radhakrishnan \\ School of Accounting and Business Management \\ FTMS COLLEGE, MALAYSIA \\ Email: grace_shalin@hotmail.com \\ Abdul Basit
School of Accounting and Business Management
FTMS COLLEGE, MALAYSIA
Email: abdulbasit@ftms.edu.my \\ Zubair Hassan \\ School of Accounting and Business Management \\ FTMS COLLEGE, MALAYSIA \\ Email: zubai7@gmail.com
}

Received: 25 June 2018/ Revised: 1 August 2018/ Accepted: 8 August 2018/Published online: 9 October 2018

\begin{abstract}
The purpose of this research is to examine the impact of social media usage on employee and organization performance. The research was done on one multinational IT Company. Social media usage was measured using knowledge sharing, decision making and communication. Organizational performance was measured using employee and organization performance. Questionnaires were developed and the items were measured using a Likert scale ranging from 1 to 5. This research takes on an explanatory approach and the sample consisting of 206 employees working in call center departments was recruited. The data was analyzed using SPSS 21 and AMOS 22 software. The results showed that only decision making has a positive and significant impact on employee high performance and organizational performance. We found no significant impact of the other two dimensions of social media usage (knowledge sharing and communication) on employee high performance and organizational performance. Therefore, this study suggests that top management in MNC companies as well as employees should consider social media usage for effective decision making to increase employee performance and organizational performance. This research contributes to existing studies on this topic, and future research could put emphasis on extending this research to another country or industry.
\end{abstract}

JEL classification: M31, M37, M39

Keywords: knowledge sharing, communication, decision making, employee high performance, organization performance. 


\section{INTRODUCTION}

The era of social media started in 1997 on its first popular site called SixDegree.com allowing users to create personal profiles and a friends list online (Boyd \& Ellison, 2007) followed by blogging platforms like Blogger and LiveJournal in 1999 and the rest such as Wikipedia in 2001, Myspace in 2003, etc. As the acceptance of these technologies widely grew, social media has moved quickly from the tech-savvy domain to the mainstream (Shirky, 2008) penetrating into organizations at a rapid pace. A survey done by McKinsey reported that $65 \%$ of organizations use social media based technologies to motivate and enhance performance (Bughin \& Chui, 2010).

However, in the past, few studies combining employee high performance and organizational performance simultaneously were carried out on the topic of social media usage in the context of Malaysia and other parts of the world. For instance, some studies examine the influence of social media on employee work performance in China (Cao et al., 2016), knowledge sharing through social media to enhance job performance in Korea (Kwahk \& Park, 2016), the link between social media and work, leadership, and work-life conflict among professionals (Jiang, Luo, \& Kulemenka, 2017), the relationship between social media usage and employee performance (Shami, Nichols, \& Chen, 2014) in the United States, and a similar study was carried out to examine the impact of social media usage on employee performance in Europe (Ouirdi et al., 2014). The number of studies carried out to examine such impact in Malaysia is considered as zero or very few. One of the recent studies on social media and its influence on employees was carried out in the oil and gas industry by Omar, Dahalan and Yusoff (2016) while another study focuses on examining the influence of social media usage on organizational performance (Parveen, Jaafar, \& Ainin, 2015). This leaves a certain gap, namely none of the studies focus on examining the impact of social media usage on employee and organizational performance. Similarly, despite the growth in the interest in social media in Malaysia, the potential value that social media gives to an organization and high rates of individual usage, studies conducted to determine social media usage and its impact within an organization are limited (Wamba \& Carter, 2013). Most of the studies carried out on social media in general focus on understanding the individual level of usage (Lundblad, 2003; Häggman, 2009). Furthermore, studies carried out in Malaysia to determine the factors affecting social media usage such as knowledge sharing, communication, decision making that enables high performance at the employee and organizational levels are considered very limited.

Therefore, the problem statement is 'what is the impact of social media usage on employee and organizational performance?' To attain the aim of the study, the following objectives were formulated:

- To examine the impact of knowledge sharing on employee high performance

- To examine the impact of communication on employee high performance

- To examine the impact of decision making on employee high performance

- To examine the impact of knowledge sharing on organization performance

- To examine the impact of communication on organization performance

- To examine the impact of decision making on organization performance

This paper is organized as follows: the introduction is the first area covered as discussed above, followed by a literature review, which mainly focuses on reviewing past research, followed by the research design and methodology, followed by findings and analysis and finally the conclusion and recommendations for future research directions. 


\section{LITERATURE REVIEW}

\section{Review of Key Concepts}

\section{Social media usage}

In general, the use of social media and the interest in it in the workplace have grown in the last few years (Lovejoy \& Saxton, 2012). The very first use of the term 'social media' is believed to have occurred in 1997, when Ted Leonsis, AOL executive, stated that organizations should provide consumers with "social media, places where they can be entertained, communicate and participate in a social environment" (Bercovici, 2010). However, according to Kaplan and Haenlein (2010), the era of social media started probably in the early 1990s, when the founders of 'Open Diary', Bruce and Susan Abelson, created an online social site which invited diary writers into one community.

Kaplan and Haenlein (2010) defined social media as a group of Internet-based applications that build on the technological and ideological foundations, which allows the creation and exchange of User-Generated Content (UGC). Similarly, Steenkamp and Hyde-Clarke (2014) defined social media as a platform which enables users of the media to exchange and share information. Also, Ouirdi et al. (2014) defined social media as a web-based and mobile platforms that allow users to share and add geographical information to user-generated content.

\section{Employee high performance}

To enable employee high performance or a high performance employee, it was argued that an organization must engage in practices for managing employee relationships to increase competencies, motivations, commitments, communication, involvement and flexibility (Sofijanova \& Zabijakin-Chatleska, 2013). It was also argued that employee high performance is achieved through basic elements such as (1) increasing employees' knowledge, skills and abilities, (2) employee empowerment and participation in decision making and problem solving and (3) motivating employees through incentives to make an additional discretionary work effort (Huselid, 1995; Mac Duffie, 1995).

Employee performance is related to the activities that are expected of a worker and how well the worker executes those activities (BusinessDictionary, 2017). Shaw (2017) stated the characteristics of high performance employees as those focused on quality as a priority in their work, concentrated on improving their skills and taking the lead when it comes to making decisions. Burks (2017) also quoted that high performers find ways to improve their performance including finding resources that they need to excel.

\section{Organization performance}

An organization is defined as a social unit comprising a group of people that is managed or structured to pursue collective goals (BusinessDictionary, 2017). In turn, performance is an exchange of non-financial and financial indicators which gives information on the achievement of the objectives and results (Lebas \& Euske, 2006). Organization performance is the outputs from the invested inputs (goals or objectives) (Lebas \& Euske, 2006)

\section{Knowledge sharing}

Alvin (1990) stated that the essence of power in the current information age is knowledge. Ryu, Ho and Han (2003) defined knowledge sharing as an act of diffusing acquired knowledge of a member to another member in an organization. Omar et al. (2016) define knowledge sharing as communicating the knowledge within a group of people whether in a formal place like the 
workplace or an informal place like among friends. On the flip side of the coin, Kwahk et al. (2016) state that knowledge sharing requires active interaction between more than one individual who has the necessary knowledge and does not depend on a single person's efforts.

\section{Communication}

Communication originated from the Latin word 'communicare' meaning "to make common" or "to share" (Weekley, 1967). Further to this, DeVito (1986) added that communication is an act or process of transmitting a message from a sender to a receiver via a channel with noise interference. Merriam Webster (2017) defines communication as an act of transmitting a verbal or written message. Team FME (2013) in their article defined communication as a two-way process which involves several interactions towards achieving mutual understanding. Bel, Smirnov and Wait (2017) state that communication is an important precursor which provides information on what to be done for a prospective change within an organization.

\section{Decision making}

Harris (2012) defines decision making as the study to identify and choose substitutes based on preferences and values of the decision maker. He also added that it is a process of adequately minimizing uncertainty and doubt about substitutes to give way to a reasonable choice to be made among them. CIMA (2007) described decision making as the steps through which alternatives are chosen and managed to achieve an organization's objectives. Chand (2016) states that a decision is a choice made by a person to conclude about a situation, while decision making is the selection of choices which involves a choice making activity that determines the person's action or inaction. According to Talley (2011), decision making includes a variety of processes that are medium steps between actions and thought which ideas are expressed.

\section{Theoretical Framework}

\section{Figure 1}

Theoretical framework for the study

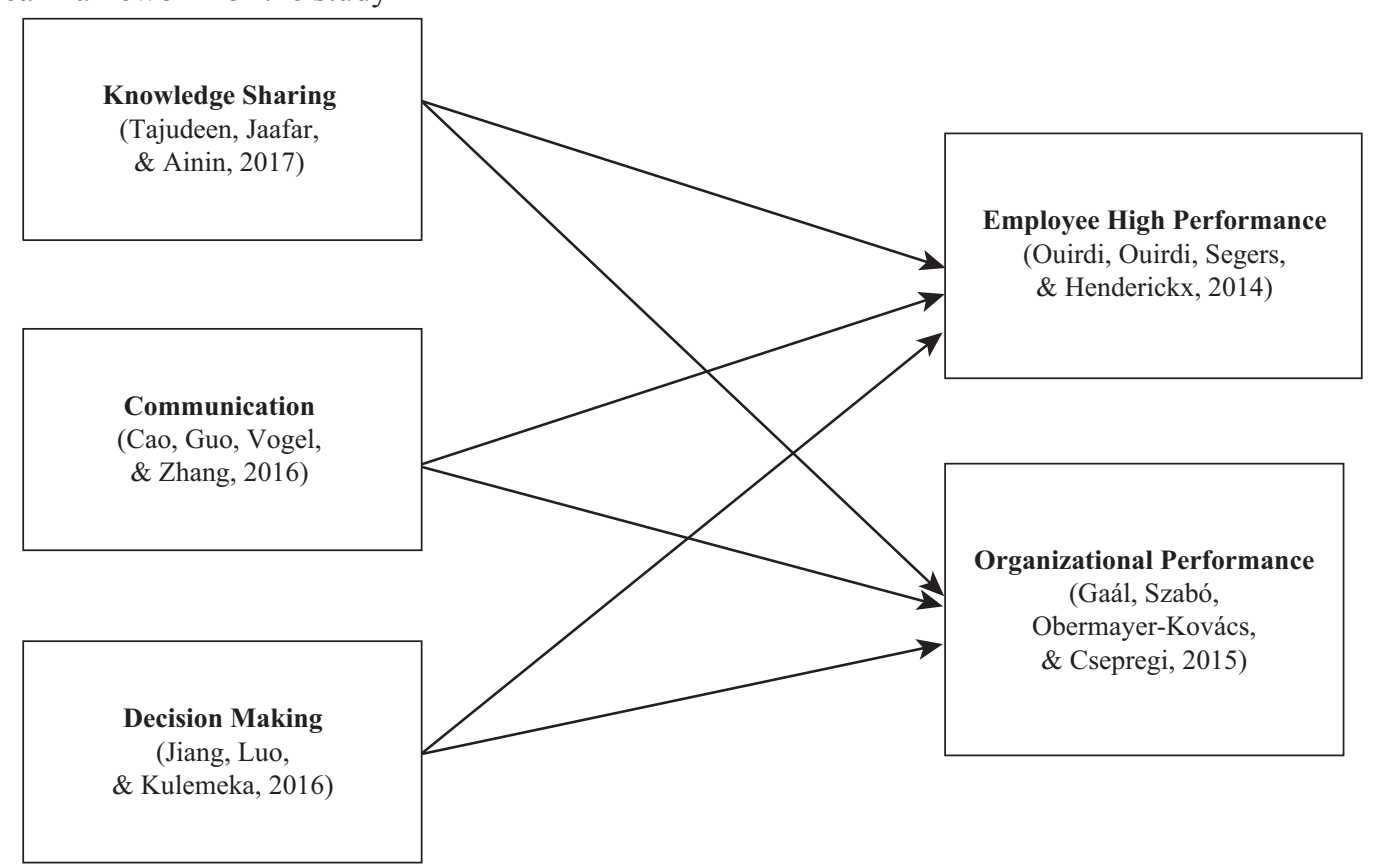




\section{Knowledge Sharing Through Social Media Usages}

Social media usage is becoming more important as these tools are being used for knowledge sharing, communication and decision making in organizations. According to Yesil and Dereli (2013), knowledge has become an important resource and a significant driver of organizational performance. By sharing knowledge, an employee in an organization can learn from other employees' experiences which in return contribute to the organization and employee job performance (Kang, Kim, \& Chang, 2008). It can also positively encourage positive team performance (Srivasta, Bartol, \& Locke, 2006) and strengthens collaboration and coordination between employees of an organization (Mathieu et al., 2000), which results in high job performance. Park and Im (2001) found that knowledge sharing does improve employees' job performance within the government sector. Sigalaa and Chalkiti (2015) explored the relation between employee creativity and social media use. They found that the use of social media for disseminating and externalizing information discussed with other peers within various social media platforms encourages employees to generate and share new knowledge. As a result, it can further expand employees' cognitive abilities through innovation and give them the opportunity to generate and create new ideas/knowledge (Sigalaa \& Chalkiti, 2015).

\section{H1: Knowledge sharing through social media usage affects employee high performance and organizational performance}

\section{Communication Through Social Media Usage}

Social media has extended itself to the communication world which gives organizations the opportunity to share information and interact frequently with their customers (Papasolomou $\&$ Melanthiou, 2012). It has also enabled a dynamic and interactive process to occur in daily communication both internally and externally between employees and the organization (Langer, 2014). Leornardi et al. (2013) argued that using social media allows employees to broadcast or communicate messages to everyone within the organization and to view the connections, text and messages posted or edited by any individual in the organization at any point of time. Also, they argued that social media platforms are digital, unlike traditional physical offices such as conference rooms, and members in the organization can communicate and participate from anywhere at any time (Leornardi et al., 2013). A recent study by Babiker (2017) found that the speed of communication via social media made the flow of information and correspondence faster.

H2: Communication through social media usage affects employee high performance and organizational performance

\section{Decision Making Through Social Media Usage}

Effective decision making depends on an individual's ability to draw from and gain access to reliable sources, which requires evaluation skills (Burclaff and Johnson, 2016). Burclaff and Johnson (2016) stated that connecting across networks with the use of social media gives the ability to make meaningful decisions on whether to acquire existing knowledge either internal or external or acquire new information. Similarly, Culnan, McHugh and Zubillaga (2010) argued that various platforms of social media give the opportunity for the organization to make a good decision on which platform to adopt and how it should be used. According to Baker et al. (2011), using social media gives leaders an opportunity to contact their subordinates fast. Papageorgiou (2015) found that employees will demonstrate high commitment to their organizations when they 
are given the opportunity to interact with other employees via internal social media platforms. This encourages employees to participate in the decision making process whereby they can voice out their concerns and issues (Papageorgiou, 2015).

H3: Decision making through social media usage affects employee high performance and organizational performance

\section{RESEARCH DESIGNS AND METHODS}

\section{Subject and Procedure Details}

The target population of this research is employees from one multinational company in Malaysia. There were almost 2006 employees working in the organization at the time of data collection.

Convenience sampling, which is a non-probability sampling method, was selected for this research as it is easy in terms of sample collection and financially cheaper as well as less time is taken to get the data; furthermore, it is a widely use technique in most research (Neuman, 2002). Within the study, 230 survey questionnaires were distributed to all the employees in the call center department. Out of 230 surveys, only 225 surveys were received back and incomplete questionnaires were eliminated. A final sample of 206 survey questionnaires that had no missing information was utilized for data analysis. This means that only $91 \%$ of the collected survey forms were usable.

Table 1 shows that $53.4 \%$ of respondents are male and the rest, that is $46.6 \%$, are female. $59.2 \%$ of respondents were within the $26-35$ age group and the fewest $(11.2 \%)$ were within the age group of 36-50.78.6\% of respondents earned a salary ranging from US\$ 500 to $1000.68 .4 \%$ of respondents were university graduates, followed by college graduates $(29.1 \%)$ and the fewest had completed secondary level education, accounting for $2.4 \%$ of all respondents.

Table 1

Demographic analysis

\begin{tabular}{|c|c|c|c|c|c|}
\hline & & Frequency & $\begin{array}{c}\text { Percentage } \\
(\%)\end{array}$ & $\begin{array}{c}\text { Valid Percentage } \\
(\%)\end{array}$ & $\begin{array}{c}\text { Cumulative } \\
\text { Percentage (\%) }\end{array}$ \\
\hline \multirow{3}{*}{ Gender } & Female & 96 & 46.6 & 46.6 & 46.6 \\
\hline & Male & 110 & 53.4 & 53.4 & 100 \\
\hline & Total & 206 & 100 & 100 & \\
\hline \multirow{4}{*}{ Age } & $18-25$ & 61 & 29.6 & 29.6 & 29.6 \\
\hline & $26-35$ & 122 & 59.2 & 59.2 & 88.8 \\
\hline & $36-50$ & 23 & 11.2 & 11.2 & 100 \\
\hline & Total & 206 & 100 & 100 & \\
\hline \multirow{4}{*}{$\begin{array}{l}\text { Education } \\
\text { Level }\end{array}$} & Secondary & 5 & 2.4 & 2.4 & 31.6 \\
\hline & College & 60 & 29.1 & 29.1 & 29.1 \\
\hline & University & 141 & 68.4 & 68.4 & 100 \\
\hline & Total & 206 & 100 & 100 & \\
\hline
\end{tabular}




\section{Research Instrument}

The researchers developed a set of questionnaires from the theoretical framework studied for this research. It was firstly tested and then utilized as primary data.

The researchers constructed the questionnaire using a Likert scale ranging from 1 to 5 , where 1 is strongly disagree and 5 indicates strongly agree for each statement (Likert, 1932). A total of 29 items or statements were developed and included in the scale construction. The research instrument, namely the questionnaire, consists of five groups of variables. Table 2 below shows the detailed construction of the questionnaire used. A sample of 50 respondents was recruited to participate in pilot testing, which was used to test the reliability and validity of the construct. As shown in Table 2 below, Cronbach's Alpha reliability test proved high reliability of all the variables as regards internal consistency since the values are above 0.8 and can be used in this research (George \& Mallery, 2003)

Table 2

Scale construction

\begin{tabular}{|c|c|c|c|c|}
\hline Variables & Q & Factors & $\begin{array}{c}\text { Pilot Testing } \\
\text { (Cronbach's Alpha } \\
\text { Reliability Test) }\end{array}$ & Source \\
\hline \multirow{5}{*}{ Knowledge Sharing } & KS1 & $\begin{array}{l}\text { Tacit and explicit } \\
\text { knowledge }\end{array}$ & \multirow{5}{*}{0.863} & \multirow{5}{*}{$\begin{array}{l}\text { Hsu et al. (2007); } \\
\text { Davenport and Prusak } \\
\text { (1998); Kwahk } \\
\text { and Park (2016); } \\
\text { Jiang, Luo and Kulemeka } \\
\text { (2017); Dhanaraj et al., } \\
\text { (2014) }\end{array}$} \\
\hline & $\mathrm{KS} 2$ & Collaboration & & \\
\hline & KS3 & $\begin{array}{l}\text { Share and exchange } \\
\text { knowledge }\end{array}$ & & \\
\hline & $\mathrm{KS} 4$ & Motivation & & \\
\hline & KS5 & $\begin{array}{l}\text { Innovatively create ideas } \\
\text { and knowledge }\end{array}$ & & \\
\hline \multirow{5}{*}{ Communication } & $\mathrm{C} 1$ & $\begin{array}{l}\text { Internal and external } \\
\text { communication }\end{array}$ & \multirow{5}{*}{0.924} & \multirow{5}{*}{$\begin{array}{l}\text { Papasolomou and } \\
\text { Melanthiou (2012); Langer } \\
\text { (2014); Farrell, Kellogg } \\
\text { and Thomas (2008); } \\
\text { Divya and Regi (2014); } \\
\text { Leornardi, et al. (2013); } \\
\text { Batikas and Van Bavel } \\
\text { (2013); Babiker (2017) }\end{array}$} \\
\hline & $\mathrm{C} 2$ & $\begin{array}{l}\text { Frequency and amount } \\
\text { of interaction }\end{array}$ & & \\
\hline & C3 & Speed of communication & & \\
\hline & $\mathrm{C} 4$ & $\begin{array}{l}\text { Broadcast or } \\
\text { communicate messages }\end{array}$ & & \\
\hline & $\mathrm{C} 5$ & $\begin{array}{l}\text { Easy use of social media } \\
\text { tool to communicate }\end{array}$ & & \\
\hline \multirow{5}{*}{ Decision Making } & DM1 & Evaluate alternatives & \multirow{5}{*}{0.926} & \multirow{5}{*}{$\begin{array}{l}\text { Burclaff and Johnson } \\
\text { (2016); Majchrzak et al. } \\
\text { (2013); Sanders (2007); } \\
\text { Leornardi (2014); Nkwe } \\
\text { and Cohen (2017); } \\
\text { Papageorgiou (2015); } \\
\text { Trimi and Galanxhi (2014) }\end{array}$} \\
\hline & DM2 & $\begin{array}{l}\text { Create decision } \\
\text { conversations leading } \\
\text { to diverse opinions }\end{array}$ & & \\
\hline & DM3 & $\begin{array}{l}\text { Make meaningful and } \\
\text { good decisions }\end{array}$ & & \\
\hline & DM4 & $\begin{array}{l}\text { Make fast decisions } \\
\text { in timely manner }\end{array}$ & & \\
\hline & DM5 & $\begin{array}{l}\text { Feel encouraged to take } \\
\text { part in making decision }\end{array}$ & & \\
\hline
\end{tabular}




\begin{tabular}{|c|c|c|c|c|}
\hline Variables & Q & Factors & $\begin{array}{c}\text { Pilot Testing } \\
\text { (Cronbach's Alpha } \\
\text { Reliability Test) }\end{array}$ & Source \\
\hline \multirow{5}{*}{$\begin{array}{l}\text { Employee } \\
\text { High Performance }\end{array}$} & EHP1 & $\begin{array}{l}\text { Perform better than } \\
\text { acceptable level }\end{array}$ & \multirow{5}{*}{0.959} & \multirow{5}{*}{$\begin{array}{l}\text { Williams and Anderson } \\
\text { (1991); Kwahk and Park } \\
\text { (2016); Ali-Hassan, Nevo } \\
\text { and Wade (2015); Kuvaas } \\
\text { (2006); Cao et al. (2016) }\end{array}$} \\
\hline & EHP2 & $\begin{array}{l}\text { Reliability of job } \\
\text { performance }\end{array}$ & & \\
\hline & EHP3 & $\begin{array}{l}\text { Ability to perform job } \\
\text { duties }\end{array}$ & & \\
\hline & EHP4 & Increased quality of work & & \\
\hline & EHP5 & $\begin{array}{l}\text { Put extra effort to } \\
\text { complete tasks on time }\end{array}$ & & \\
\hline \multirow{5}{*}{$\begin{array}{l}\text { Organization } \\
\text { Performance }\end{array}$} & OP1 & Improve client service & \multirow{5}{*}{0.950} & \multirow{5}{*}{$\begin{array}{l}\text { Wu (2016); Tajudeen, } \\
\text { Jaafar and Ainin (2017); } \\
\text { Parveen et al. (2016) }\end{array}$} \\
\hline & OP2 & $\begin{array}{l}\text { Introduce new social } \\
\text { media tool }\end{array}$ & & \\
\hline & OP3 & $\begin{array}{l}\text { Seek new ways } \\
\text { to do things }\end{array}$ & & \\
\hline & OP4 & $\begin{array}{l}\text { Interact with employees } \\
\text { and clients }\end{array}$ & & \\
\hline & OP5 & $\begin{array}{l}\text { Encourage use of social } \\
\text { media }\end{array}$ & & \\
\hline
\end{tabular}

\section{RESULTS AND ANALYSIS}

This part of the paper will discuss the validity, reliability of the research instrument and findings through appropriate data analysis methods. The validity test of the item construction is done through a confirmatory factor analysis. The reliability test is conducted using Cronbach's alpha via SPSS. The path analysis is conducted using Structural Equation Modeling (SEM).

\section{Confirmatory Factor Analysis (CFA)}

Figure 2

Measurement model (CFA)

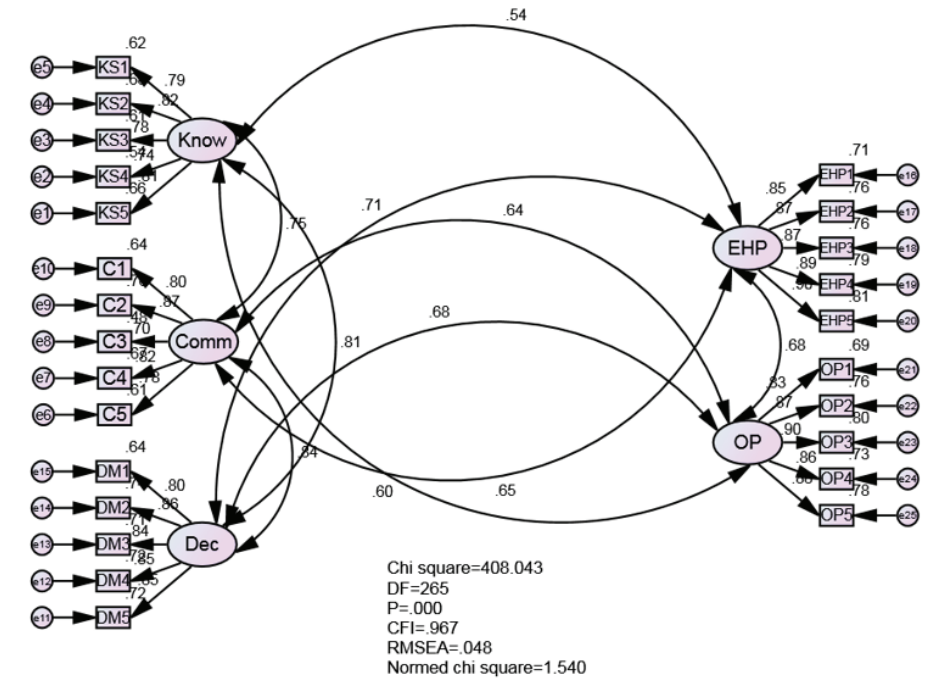


According to Holmes-Smith (2006) and Hair et al. (2010), the model fitness indices indicate the level of acceptance for the confirmatory factor analysis. The analysis for most items must be within the construct and loading factors must have a score above 0.5 to show good reliability of the model (Holmes-Smith, 2001). Thus, in Figure 2, the estimates of above 0.6 for all the variables show that the overall model is valid for further analysis. According to Hair et al. (2010), the Comparative Fit Index (CFI) should exceed 0.90 to achieve a good model fit and in this research the CFI value is 0.967 , which is considered as good fit. To indicate the statistics fitness, the normed chi-square ratio should be below 3.0 according to Kline (2011) and in this research, it is 1.54 . The Root Mean Square Error (RMSEA) value is 0.048 and is below the recommended max value level of 0.08 indicating a good fit (Hooper et al., 2008).

Overall, the RMSEA value of 0.048 and CFI value of 0.967 show that the model is accepted as a good fit (Themessl-Huber, 2014). To ensure the model fitness, the convergent validity is established to measure social media usage, which measures employee high performance (EHP) and organization performance (OP).

According to Hair et al. (2010), the rule of thumb for factor loadings must be 0.5 and above while the best is 0.7 and above.

Table 3

Divergent validity measurement

\begin{tabular}{|c|c|c|c|c|c|}
\hline & $\begin{array}{l}\text { Knowledge } \\
\text { Sharing }\end{array}$ & Communication & Decision Making & $\begin{array}{l}\text { Employee High } \\
\text { Performance }\end{array}$ & $\begin{array}{l}\text { Organization } \\
\text { Performance }\end{array}$ \\
\hline KS1 & .790 & & & & \\
\hline KS2 & .824 & & & & \\
\hline KS3 & .783 & & & & \\
\hline KS4 & .737 & & & & \\
\hline KS5 & .815 & & & & \\
\hline $\mathrm{C} 1$ & & .798 & & & \\
\hline $\mathrm{C} 2$ & & .873 & & & \\
\hline C3 & & .696 & & & \\
\hline $\mathrm{C4}$ & & .820 & & & \\
\hline C5 & & .784 & & & \\
\hline DM1 & & & .800 & & \\
\hline DM2 & & & .860 & & \\
\hline DM3 & & & .844 & & \\
\hline DM4 & & & .851 & & \\
\hline DM5 & & & .850 & & \\
\hline EHP1 & & & & .845 & \\
\hline EHP2 & & & & .874 & \\
\hline EHP3 & & & & .871 & \\
\hline EHP4 & & & & .889 & \\
\hline EHP5 & & & & .898 & \\
\hline OP1 & & & & & .833 \\
\hline OP2 & & & & & .869 \\
\hline OP3 & & & & & .896 \\
\hline OP4 & & & & & .857 \\
\hline OP5 & & & & & .881 \\
\hline Reliability & 0.892 & 0.892 & 0.924 & 0.942 & 0.938 \\
\hline
\end{tabular}


As in the table above (Table 3), all the factor loadings (independent and dependent variables) are above 0.5 , which confirms the model fitness as good fit, and the reliability of the constructs is above 0.60 for KS, C, DM, EHP and OP. As for the reliability, the acceptable value of Cronbach's alpha is a minimum value of 0.7 (Nunnally \& Bernstein, 1994), which indicates that the variables in this study are highly reliable in internal consistency as they are above 0.8 and are best suited for further analysis.

Discriminant validity determines the measure of how much factors are different and the level of how much they are swerved. In theory, the constructs must not correlate with each other. According to Hair et al. (2010), the correlation values must not exceed 0.85. Likewise, discriminant validity indicates the squared correlations whereby all the values are lesser than 1 indicating that the construct validity is acceptable (Hair et al., 2010). Discriminant validity cannot be established when the factor analysis is miscalculated or misunderstood (Bajpai \& Bajpai, 2014). Therefore, in the table below (Table 4), the data in this research satisfies discriminant validity and the factors indicate a good correlation as the values are below 0.85 .

Table 4

Discriminant validity measurement

\begin{tabular}{l|c|c|c|c|c} 
& Knowledge Sharing & Communication & Decision Making & $\begin{array}{c}\text { Employee High } \\
\text { Performance }\end{array}$ & $\begin{array}{c}\text { Organization } \\
\text { Performance }\end{array}$ \\
\hline KS & 1 & .749 & .811 & .541 & .602 \\
\hline C & .561 & 1 & .840 & .651 & .638 \\
\hline DM & .657 & .705 & 1 & .711 & .679 \\
\hline EHP & .292 & .423 & .505 & 1 & .678 \\
\hline OP & .362 & .407 & .461 & .459 & 1
\end{tabular}

Significant Level at $\mathrm{p}=0.001$. Values above the diagonals are correlations among constructs. Diagonal elements are construct variance and values below the diagonal are squared correlations

\section{Structural Equation Model}

Figure 3

Path analysis of SEM

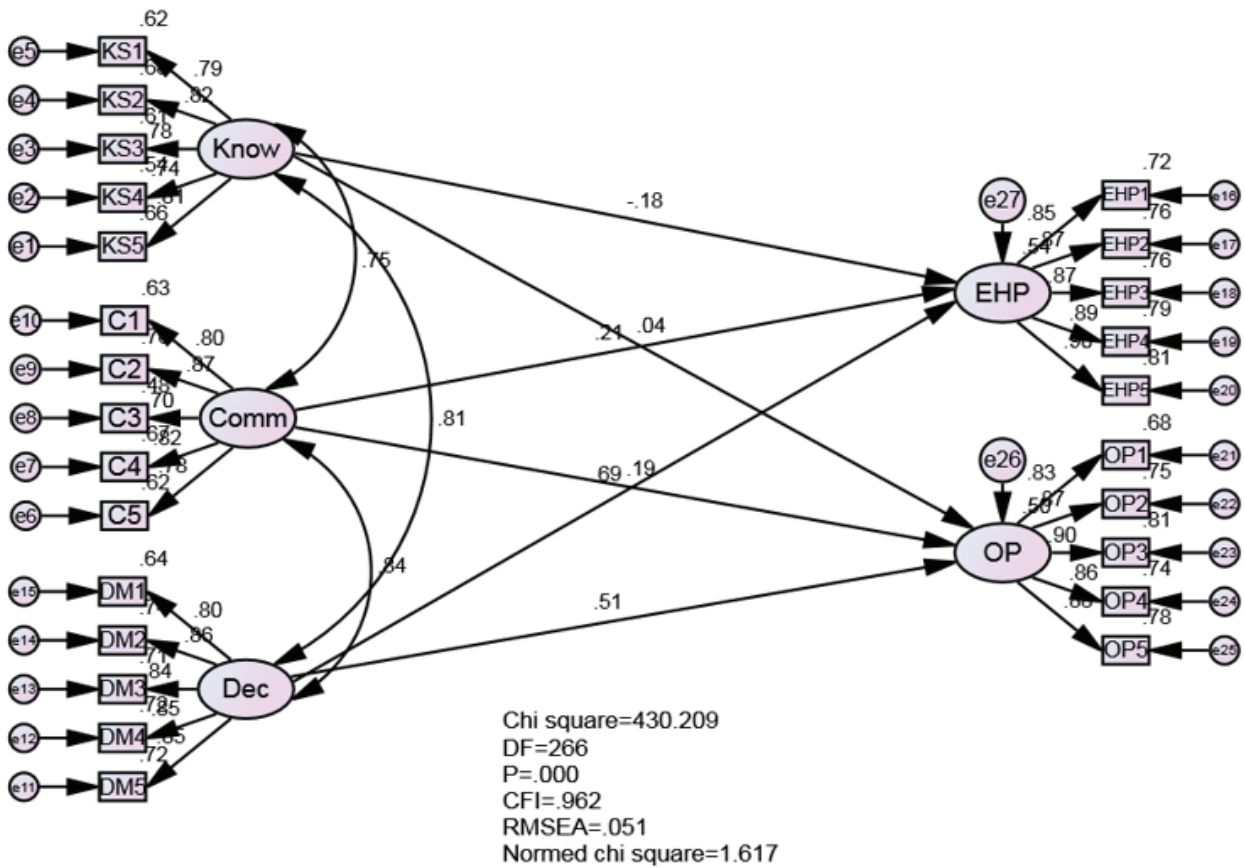


The measurement model of confirmatory factor analysis plays an important role to confirm the structural model analysis. In the structural model, the chi-square value is 430.209 while the DF value is 266 . The normed chi-square value is 1.617 , below the recommended threshold value of 3.0, revealing a good fit model (Hair et al., 2010). The RMSEA value of 0.051 is at the required threshold of less than 0.08. CFI is 0.962 , above the rule of thumb of 0.90 (Hair et al., 2010; Kline, 2011). Hence, the structural model is considered as an acceptable model.

Table 5

Comparison of measurement and structural model

\begin{tabular}{|c|c|c|c|c|c|c|}
\hline & Chi-Square & DF & $\begin{array}{l}\text { Normed } \\
\text { Chi-Square }\end{array}$ & CFI & RMSEA & P-value \\
\hline Rule of Thumb & & & $<3$ & $>0.900$ & $<0.08$ & $>0.05$ \\
\hline $\begin{array}{l}\text { Measurement Model } \\
\text { (MM) CFA }\end{array}$ & 408.043 & 265 & 1.540 & 0.967 & 0.048 & 0.0001 \\
\hline Structural Model (SM) & 430.209 & 266 & 1.617 & 0.962 & 0.051 & 0.0001 \\
\hline
\end{tabular}

According to Hair et al. (2010), there is an alternative way to confirm the model validity by observing the entire structural model loadings and measurement model loadings. The parameter estimates must show a similar likeness in both models (Hair et al., 2010). In Table 5 above, there are almost close readings indicating only a slight difference in both models, p-value is 0.000 for both, RMSEA is $0.048(\mathrm{MM})$; $0.051(\mathrm{SM}), \mathrm{CFI}$ is $0.967(\mathrm{MM}) ; 0.962(\mathrm{SM})$, normed chi-square is $1.540(\mathrm{MM}) ; 1.617(\mathrm{SM}), \mathrm{DF}$ is $265(\mathrm{MM}) ; 266(\mathrm{SM})$ and chi-square is $408.043(\mathrm{MM}) ; 430.209$ (SM). Therefore, the SEM confirms the validity of the model as the loadings on both CFA and SEM are similar and there is no significant variation (Hair et al., 2010).

Table 6

Comparison of factor loadings

\begin{tabular}{llcc} 
& \multicolumn{1}{c}{ Construct } & Measurement Model & Structural Model \\
\hline KS1 & Knowledge Sharing & .790 & .790 \\
\hline KS2 & Knowledge Sharing & .824 & .824 \\
\hline KS3 & Knowledge Sharing & .783 & .783 \\
\hline KS4 & Knowledge Sharing & .737 & .737 \\
\hline KS5 & Knowledge Sharing & .815 & .815 \\
\hline C1 & Communication & .798 & .798 \\
\hline C2 & Communication & .873 & .873 \\
\hline C3 & Communication & .696 & .696 \\
\hline C4 & Communication & .820 & .820 \\
\hline C5 & Communication & .784 & .784 \\
\hline DM1 & Decision Making & .800 & .800 \\
\hline DM2 & Decision Making & .860 & .860 \\
\hline DM3 & Decision Making & .844 & .844 \\
\hline DM4 & Decision Making & .851 & .851 \\
\hline DM5 & Decision Making & .850 & .850 \\
\hline EHP1 & Employee High Performance & .845 & .845 \\
\hline
\end{tabular}




\begin{tabular}{llcc} 
& \multicolumn{1}{c}{ Construct } & Measurement Model & Structural Model \\
\hline EHP2 & Employee High Performance & .874 & .874 \\
\hline EHP3 & Employee High Performance & .871 & .871 \\
\hline EHP4 & Employee High Performance & .889 & .889 \\
\hline EHP5 & Employee High Performance & .898 & .898 \\
\hline OP1 & Organization Performance & .833 & .833 \\
\hline OP2 & Organization Performance & .869 & .869 \\
\hline OP3 & Organization Performance & .896 & .896 \\
\hline OP4 & Organization Performance & .857 & .857 \\
\hline OP5 & Organization Performance & .881 & .881
\end{tabular}

The above Table 6 shows the factor loadings of the structural model and measurement model as all values are above 0.50 and resemblance of $100 \%$ is achieved between the two models. This indicates that the model is valid and a good fit model.

\section{Hypothesis Testing}

The table below (Table 7) presents the results of hypothesis testing of Estimate, S.E. (Standard Errors), C.R (Critical Rations) and the p-value. P-value indicates the significance level of each hypothesis (Hair et al., 2010).

Table 7

Hypotheses

\begin{tabular}{|c|c|c|c|c|c|c|c|c|}
\hline Hypothesis & & & & Estimate & S.E. & C.R. & $\mathbf{P}$ & $\begin{array}{l}\text { Accepted } \\
\text { or Rejected }\end{array}$ \\
\hline H1 & $\begin{array}{l}\text { Employee High } \\
\text { Performance }\end{array}$ & $\leftarrow$ & $\begin{array}{l}\text { Knowledge } \\
\text { Sharing }\end{array}$ & -.178 & .115 & -1.548 & .122 & Rejected \\
\hline H2 & $\begin{array}{l}\text { Employee High } \\
\text { Performance }\end{array}$ & $\leftarrow$ & Communication & .227 & .136 & 1.662 & .097 & Rejected \\
\hline H3 & $\begin{array}{l}\text { Employee High } \\
\text { Performance }\end{array}$ & $\leftarrow$ & Decision Making & .689 & .148 & 4.639 & .0001 & Accepted \\
\hline H4 & $\begin{array}{l}\text { Organization } \\
\text { Performance }\end{array}$ & $\leftarrow$ & $\begin{array}{l}\text { Knowledge } \\
\text { Sharing }\end{array}$ & .043 & .119 & .367 & .714 & Rejected \\
\hline H5 & $\begin{array}{l}\text { Organization } \\
\text { Performance }\end{array}$ & $\leftarrow$ & Communication & .215 & .143 & 1.504 & .133 & Rejected \\
\hline H6 & $\begin{array}{l}\text { Organization } \\
\text { Performance }\end{array}$ & $\leftarrow$ & Decision Making & .515 & .151 & 3.406 & .0001 & Accepted \\
\hline
\end{tabular}

Knowledge Sharing is the only variable that has an insignificant negative impact on employee high performance. It is also the only variable that has a positive and significant impact on Employee High Performance and Organization Performance. All the other variables (Knowledge Sharing and Communication) identified in the conceptual framework are found to be insignificant due to the significance value that exceeds the threshold of 0.05 meaning that the assumed Hypotheses 1 , 2,4 and 5 are rejected. This is in accordance with the rule of thumb that the p-value should be 0.05 and below; thus, each time when the value is more than 0.05 , the hypothesis is rejected (Hair et al., 2010). 
The 1st hypothesis of this research is that there is a positive and significant impact of knowledge sharing on employee high performance based on the research done by Sigalaa and Chalkiti (2015) in Greece, Huang, Singh and Ghose (2015) on Fortune 1000 companies in the USA, Europe, Asia and North America as well as Mohamed et al. (2017) in Malaysia, finding that innovative learning and creating new ideas/knowledge, sharing tacit and explicit knowledge, motivating and collaborating are important factors in knowledge sharing through the use of social media and have a positive impact on employee performance. However, the result of this study conflicts with the hypothesis set by this study as it is rejected with the standardized estimate of -0.178 and the $p$-value of 0.122 . The findings show that knowledge sharing has an insignificant negative impact on employee high performance, which contradicts the past research (Sigalaa \& Chalkiti, 2015; Huang, Singh, \& Ghose, 2015; Mohamed et al., 2017). This research is done on call center agents in an IT based multinational in Malaysia, where the nature of work by the agents is more oriented towards attending calls and it takes time and effort for them to engage in knowledge sharing activities with other peers. However, the statistical analysis of this study finds no significant impact of knowledge sharing on employee performance.

The 2 nd hypothesis of this research is that there is a positive and significant impact of communication on employee high performance, which is in accordance with past research done by Divya and Regi (2014) in India, Babiker (2017) in UAE, Kaur (2015) in Lynas and Mohamed et al. (2017) in Malaysia. It was found that social media assist internal and external communication by broadcasting messages and increasing the speed of communication causing a positive impact on employee performance. However, our result is inconsistent with the above mentioned studies. We found a positive but not significant impact of communication elements of social media on employee performance.

The 3rd hypothesis of this research is that there is a positive and significant impact of decision making on employee high performance. The results of this research supported the hypothesis with the standardized estimate of 0.689 and p-value of less than 0.05 indicating a highly significant positive impact on employee high performance. These results support the studies done by Papageorgiou (2015), Nkwe and Cohen (2017), Burclaff and Johnson (2016), who found that the usage of social media across networks enables employees to make meaningful and fast decisions and evaluate alternatives. These elements are visible through the usage of social media tools whereby the call center agents can use various social media tools available in the IT based multinational in Malaysia to make fast decisions and evaluate available alternatives. Among peers, they can create decision conversations and diverse opinions enable them to perform better than the acceptable level (Omar, Dahalan, \& Yusof, 2016).

The 4th hypothesis of this research is that there is a positive and significant impact of knowledge sharing on organizational performance. According to the research done by Hung et al. (2011) on 10 organizations in Taiwan, organizational culture motivates employees to share knowledge, indirectly increasing organizational performance. Park and Im (2001) as well as Kang, Kim, and Chang (2008) found that organizational performance increases when employees are encouraged to share knowledge and collaborate to develop new ideas, solve problems and implement processes toward success of the organization. However, our finding conflicts with the stated hypothesis as it is rejected with the standardized estimate of 0.043 and the $p$-value of 0.714 . The findings show that knowledge sharing has an insignificant positive impact on organization performance. This could be because the management team within the IT based multinational's call center department does not encourage the employees or the management itself to undertake knowledge sharing activities or takes less initiative in this respect. Successful organizations frequently engage in knowledge sharing activities via their technologies, services and products (Gaál et al., 2008; Gottschalk, 2006).

The 5th hypothesis of this research is that there is a positive and significant impact of communication on organization performance in parallel with the studies done by Papasolomou and Melanthiou (2012) finding that the usage of social media gave organizations the opportunity 
to share information and interact frequently with their customers thus increasing organization performance, while McQuail (2013) found that those organizations which use multiple social media to communicate with their customers have higher propensity to attract more customers and can improve organizational performance. However, the results of this research found that communication has an insignificant positive impact on organization performance with a standardized estimate of 0.215 and the $\mathrm{p}$-value of 0.133 . Although the standard estimate of 0.215 indicates a positive impact, it is not considered as an important factor in contributing to organization performance. This could be because communication via social media has been a norm in almost all organizations as organizations are now moving from traditional offices such as conference rooms and their members can communicate and participate from anywhere at any time (Leornardi et al., 2013). Hence, it does not give any special advantage for an organization to perform better than others; neither is it an important factor that contributes to the success of the organization.

The 6th hypothesis of this research is that there is a positive and significant impact of decision making on organization performance. The results of this research supported the hypothesis with the standardized estimate of 0.515 and the p-value of less than 0.05 indicating a significant positive impact on organization performance. This further supports past research results such as Culnan, McHugh and Zubillaga (2010), who noted that in the various platforms of social media, it gives the opportunity for the organizations in the USA to make a good decision on which platform to adopt and how it should be used. Besides, Baker et al. (2011) found that using social media gives leaders an opportunity to contact their subordinates fast. If there is an issue that requires quick attention, managers can contact their employees through social media tools and acquire the information they need to make a fast decision. Employees can also make a fast decision using social media, which in turn increases their productivity. This indirectly improves organization performance as issues can be solved within a short frame of time (Baker et al., 2011). Further, the IT based multinational in Malaysia encourages its employees to take part in making decisions via its social media tools as well as suggest solutions and voice out their concerns through a social media platform (Nkwe \& Cohen, 2017).

Table 8

Hypothesis acceptance or rejection

\begin{tabular}{|c|c|c|c|c|}
\hline Hypothesis & Research Result & Past Research Result & Source & $\begin{array}{l}\text { Accepted } \\
\text { or Rejected }\end{array}$ \\
\hline $\begin{array}{l}\text { Knowledge Sharing } \\
>\text { Employee High } \\
\text { Performance }\end{array}$ & $\begin{array}{l}\text { Insignificant } \\
\text { negative impact }\end{array}$ & $\begin{array}{l}\text { same result }> \\
\text { opposite result }>\end{array}$ & $\begin{array}{l}\text { Gaal et al. (2015) } \\
\text { Kwahk and Park (2015) }\end{array}$ & Rejected \\
\hline $\begin{array}{l}\text { Communication } \\
\text { > Employee High } \\
\text { Performance }\end{array}$ & $\begin{array}{l}\text { Insignificant } \\
\text { positive impact }\end{array}$ & $\begin{array}{l}\text { same result }> \\
\text { opposite result }>\end{array}$ & $\begin{array}{l}\text { Leornardi et al. (2013) } \\
\text { El Ouirdi et al. (2016) }\end{array}$ & Rejected \\
\hline $\begin{array}{l}\text { Decision Making } \\
>\text { Employee High } \\
\text { Performance }\end{array}$ & $\begin{array}{l}\text { Significant } \\
\text { Positive Impact }\end{array}$ & $\begin{array}{l}\text { same result }> \\
\text { opposite result }>\end{array}$ & $\begin{array}{l}\text { Papageorgiou (2015) } \\
\text { Stollak et al. (2014) }\end{array}$ & Accepted \\
\hline $\begin{array}{l}\text { Knowledge Sharing }> \\
\text { Organization Performance }\end{array}$ & $\begin{array}{l}\text { Insignificant } \\
\text { positive impact }\end{array}$ & $\begin{array}{l}\text { same result }> \\
\text { opposite result }>\end{array}$ & $\begin{array}{l}\text { Kromhout (2011) } \\
\text { Razmerita, Kirchner and } \\
\text { Nielsen }(2016)\end{array}$ & Rejected \\
\hline $\begin{array}{l}\text { Communication }> \\
\text { Organization Performance }\end{array}$ & $\begin{array}{l}\text { Insignificant } \\
\text { positive impact }\end{array}$ & $\begin{array}{l}\text { same result }> \\
\text { opposite result }>\end{array}$ & $\begin{array}{l}\text { Juang et al. (2015) } \\
\text { Kwakh and Park (2016) }\end{array}$ & Rejected \\
\hline $\begin{array}{l}\text { Decision Making > } \\
\text { Organization Performance }\end{array}$ & $\begin{array}{l}\text { Significant } \\
\text { Positive Impact }\end{array}$ & $\begin{array}{l}\text { same result }> \\
\text { opposite result }>\end{array}$ & $\begin{array}{l}\text { Nkwe and Cohen (2017) } \\
\text { Culnan, McHugh and } \\
\text { Zubillaga (2010) }\end{array}$ & Accepted \\
\hline
\end{tabular}




\section{CONCLUSION AND RECOMMENDATIONS}

The main objective of this research was to examine the impact of social medial usage on employee high performance and organization performance. From the empirical research, three major determinants that have an impact on employee high performance and organization performance were identified: knowledge sharing, communication and decision making. Two research objectives related to decision making were the spotlight in this research as it resulted with a positive influence on both dependent variables. The findings reflect decision making as an important factor that contributes to employee high performance and organization performance. Overall, management in organizations who aims to increase employee and organization performance should consider using social media for decision making.

\section{Recommendations}

Further to the conclusions above, recommendations to raise the bar of social media usage and perceived effectiveness in employee and organization performance are as below.

Firstly, as social media continues to expand due to the rapid change of technology and many organization are jumping on its bandwagon, it is expected that the influence of social media on organizations and their employees will direct firms towards embracing social media due to increased importance of its use. Hence, firms that use social media due to its influence within the industry must also be aware of its technical applications to reap its benefits by achieving better employee and organizational performance.

Secondly, the results obtained from this research will give a broader understanding to employees in general and the management of MNCs in Malaysia of the impact of social media usage on employee and organization performance. With the growing social media trend and challenging business environment, organizations and employees must be able to keep up with the trend and utilize social media in their daily work to avoid being left behind and submerged in the competitive environment. Therefore, using social media is a key contributor for employees and organizations to attaining the peak of their performance for competitive advantage.

Lastly, the findings of this study are highly recommended to HR departments, managers and those in top management in MNCs to engage in developing social media practices for high performance. This will enable employees to engage in and focus on decision making to enable organizations and their employees to achieve better performance.

\section{Future Research Directions}

This research dealt with the impact of social media usage on employee high performance and organization performance, specifically focusing on an IT based multinational in Malaysia. The following suggestions can be made for future research.

Firstly, sample respondents of this research were recruited from among call center agents in an IT based multinational in Malaysia. As the nature of their work differs from that of other employees in the IT based multinational in Malaysia, the results do not fully represent that IT based multinational in Malaysia, hence future research can focus on employees from various department as well as from other countries, for example Asian or Western countries like India or the USA.

Secondly, research can also be done on other industries than MNCs to evaluate how effectively the usage of social media influences employee and organization performance in other industries.

Thirdly, the sample size should increase to get more accurate data according to Comrey and Andrew (1992), 1000 respondents and above are accepted as an excellent and perfect sample size.

Fourthly, future studies could test other dimensions of social media which are more prevalent among users. 
Lastly, future research should consider adapting a longitudinal design approach to observe the changes in the impact of social media usage on employee and organization performance over time using the organizational and employee performance measures used in this study.

\section{References}

Ali-Hassan, H., Nevo, D., \& Wade, M. (2015). Linking dimensions of social media use to job performance: The role of social capital. The Journal of Strategic Information Systems, 24(2), 65-89.

Alvin, T. (1990). Power shift. Knowledge, wealth and violence at the edge of the 21 st century.

Babiker, M.E.I. (2017). An evaluation of the use of social media and how it affects productivity/cost effectiveness at the workplace (Doctoral dissertation). Cardiff Metropolitan University.

Bajpai, S. \& Bajpai, R. (2014). Goodness of measurement: Reliability and validity.

Baker, D., Buoni, N., Fee, M., \& Vitale, C. (2011). Social networking and its effects on companies and their employees.

Batikas, M. \& Van Bavel, R. (2013). Assessing the benefits of social networks for organizations (No. JRC85669). Joint Research Centre (Seville site).

Bel, R., Smirnov, V., \& Wait, A. (2018). Managing change: Communication, managerial style and change in organizations. Economic Modelling, 69, 1-12.

Bercovici, J. (2010, December 9). Who coined "social media"? Web pioneers compete for credit. Retrieved from http://blogs.forbes.com/jeffbercovici/2010/12/09/ who-coined-social-media-web-pioneers-compete-forcredit/ (14 October 2017).

Boyd, D.M. \& Ellison, N.B. (2007). Social network sites: Definition, history, and scholarship. Journal of ComputerMediated Communication, 13, 210-230.

Bughin, J. \& Chui, M. (2010, December). The rise of the networked enterprise: Web 2.0 finds its payday. McKinsey Quarterly (online). Retrieved from http://www.mckinsey- quarterly.com (27 December 2017).

BusinessDictionary. (2017). Definition of organization (online). Retrieved from http://www.businessdictionary.com/ definition/organization.html (11 October 2017).

Burclaff, N. \& Johnson, C.R. (2016). Teaching information literacy via social media: An exploration of connectivism.

Burks, F (2017). What distinguishes a high-performing employee from an average performer? (online). Retrieved from http://smallbusiness.chron.com/distinguishes-highperforming-employee-average-performer-39432.html (11 October 2017).

Cao, X., Guo, X., Vogel, D., \& Zhang, X. (2016). Exploring the influence of social media on employee work performance. Internet Research, 26(2), 529-545.

Chand, S. (2016). Decision making in management: Definition and Features - Explained! (online). Retrieved from http://www.yourarticlelibrary.com/decision-making/decision-making-in-management-definition-andfeatures-explained/25657/ (6 October 2017).

CIMA. (2007) Effective decision making (online). Retrieved from http://www.cimaglobal.com/Documents/ ImportedDocuments/40_Effective_Decision_Making.pdf (5 October 2017).

Comrey, A.L. \& Lee, H.B. (1992). A first course in factor analysis (2 $2^{\text {nd }}$ ed.). Hillsale, New Jersey: Erlbaum.

Culnan, M.J., McHugh, P.J., \& Zubillaga, J.I. (2010). How large US companies can use Twitter and other social media to gain business value. MIS Quarterly Executive, 9(4).

Davenport, T.H. \& Prusak, L. (1998). Working knowledge: How organizations manage what they know. Harvard Business Press.

DeVito, J.A. (1986). The communication handbook: A dictionary. Harpercollins.

Dhanaraj, C., Lyles, M.A., Steensma, H.K., \& Tihanyi, L. (2004). Managing tacit and explicit knowledge transfer in IJVs: The role of relational embeddedness and the impact on performance. Journal of International Business Studies, 35(5), 428-442.

Divya, S. \& Regi, B. (2014). An empirical study on effectiveness of social media as a marketing tool. International Journal of Current Research and Academic Review.

Farrell, R.G., Kellogg, W.A., \& Thomas, J.C. (2008). The participatory web and the socially resilient enterprise. In Proceedings of CSCW (pp. 64-74). IBM TJ Watson Research Center.

Gaál, Z., Szabó, L., Obermayer-Kovács, N., \& Csepregi, A. (2015). Exploring the role of social media in knowledge sharing. Electronic Journal of Knowledge Management, 13(3).

George, D. \& Mallery, M. (2003). Using SPSS for Windows step by step: A simple guide and reference.

Gottschalk, P. (Ed.). (2006). CIO and corporate strategic management: Changing role of CIO to CEO. IGI Global.

Häggman, S.K. (2009). Functional actors and perceptions of innovation attributes: influence on innovation adoption. European Journal of Innovation Management, 12(3), 386-407. 
Hair Jr., J.F., Black, W.C., Babin, B.J., \& Anderson, R.E. (2010). Multivariate data analysis - A global perspective (7th ed.). Upper Saddle River: Pearson Education.

Harris, R. (2012). Introduction to decision making (online). Retrieved from http://www.virtualsalt.com/crebook5.htm (5 October 2017).

Holmes-Smith, P. (2001). Introduction to structural equation modeling using LISREL. Perth: ACSPRI-Winter training program.

Holmes-Smith, P., Coote, L., \& Cunningham, E. (2006). Structural equation modeling: From the fundamentals to advanced topics. Melbourne: SREAMS.

Hsu, M.H., Ju, T.L., Yen, C.H., \& Chang, C.M. (2007). Knowledge sharing behavior in virtual communities: The relationship between trust, self-efficacy, and outcome expectations. International Journal of HumanComputer Studies, 65(2), 153-169.

Huang, Y., Singh, P.V., \& Ghose, A. (2015). A structural model of employee behavioral dynamics in enterprise social media. Management Science, 61(12), 2825-2844.

Hung, S.Y., Lai, H.M., \& Chang, W.W. (2011). Knowledge-sharing motivations affecting R\&D employees’ acceptance of electronic knowledge repository. Behaviour \& Information Technology, 30(2), 213-230.

Jiang, H., Luo, Y., \& Kulemeka, O. (2017). Strategic social media use in public relations: Professionals' perceived social media impact, leadership behaviors, and work-life conflict. International Journal of Strategic Communication, 11(1), 18-41.

Kang, Y.J., Kim, S.E., \& Chang, G.W. (2008). The impact of knowledge sharing on work performance: An empirical analysis of the public employees' perceptions in South Korea. Intl Journal of Public Administration, 31(14), 1548-1568.

Kaplan, A.M. \& Haenlein, M. (2010). Users of the world, unite! The challenges and opportunities of social media. Business Horizons, 53(1), 59-68.

Kaur, K. (2015). Social media creating digital environmental publics: Case of Lynas Malaysia. Public Relations Review, 41(2), 311-314.

Kline, R. B. (2011). Principles and practice of structural equation modeling. New York: Guilford Press.

Kromhout, P.J. (2011). The effect of media usage, trust, and relations on the productivity, innovativeness and flexibility of teleworkers, and how knowledge sharing and telework frequency influences these relationships. Erasmus Universiteit.

Kuvaas, B. (2006). Work performance, affective commitment, and work motivation: The roles of pay administration and pay level. Journal of Organizational Behavior, 27(3), 365-385.

Kwahk, K.Y. \& Park, D.H. (2016). The effects of network sharing on knowledge-sharing activities and job performance in enterprise social media environments. Computers in Human Behavior, 55, 826-839.

Langer, E. (2014). What's trending? Social media and its effects on organizational communication. Journal of Undergraduate Research, 17, 1-14.

Lebas, M., \& Euske, K. (2004). A conceptual and operational delineation of performance. In A. Neely (ed.), Business performance measurement. Theory and practice (pp. 65-79). Leonardi, P.M. (2014). Social media, knowledge sharing, and innovation: Toward a theory of communication visibility. Information Systems Research, 25(4), 796-816.

Leonardi, P.M., Huysman, M., \& Steinfield, C. (2013). Enterprise social media: Definition, history, and prospects for the study of social technologies in organizations. Journal of Computer-Mediated Communication, 19(1), $1-19$.

Likert, R. (1932). A technique for the measurement of attitudes. Archives of Psychology.

Lovejoy, K. \& Saxton, G.D. (2012). Information, community, and action: How nonprofit organizations use social media. Journal of Computer-Mediated Communication, 17(3), 337-353.

Lundblad, J.P. (2003). A review and critique of Rogers' diffusion of innovation theory as it applies to organizations. Organization Development Journal, 21(4), 50-64.

Majchrzak, A., Faraj, S., Kane, G.C., \& Azad, B. (2013). The contradictory influence of social media affordances on online communal knowledge sharing. Journal of Computer-Mediated Communication, 19(1), 38-55.

Mathieu, J.E., Heffner, T.S., Goodwin, G.F., Salas, E., \& Cannon-Bowers, J.A. (2000). The influence of shared mental models on team process and performance. Journal of Applied Psychology, 85(2), 273-283.

Merriam Webster. (2017). Definition of employee (online). Retrieved from http://smallbusiness.chron.com/ characteristics-high-performance-employee-41338.html (9 October 2017).

McQuail, D. (2013). Communication research paradigms-reflections on paradigm change in communication theory and research. International Journal of Communication, 7(2013), 216-229. Retrieved from ijoc.org/index. php/ijoc/article/download/1961/850 (19 September 2018).

Mohamed, S., Safiah, S., Kudus, N., Hassan, M.A., \& Izharrudin, S.Z. (2017). The instrument used in measuring employee productivity based on social media usage: A review. Journal of Human Capital Development (JHCD), 10(1).

Neuman, L.W. (2002). Social research methods: Qualitative and quantitative approaches. 
Nkwe, N. \& Cohen, J. (2017). Impact of social network sites on psychological and behavioural outcomes in the work-place: A systematic literature review.

Nunnally, J. C., \& Bernstein, I. H. (1994). Psychometric theory (McGraw-Hill Series in Psychology, Vol. 3). New York: McGraw-Hill.

Omar, M.K., Dahalan, N.A., \& Yusoff, Y.H.M. (2016). Social media usage, perceived team-efficacy and knowledge sharing behaviour among employees of an oil and gas organisation in Malaysia. Procedia Economics and Finance, 37, 309-316.

Ouirdi, M.E., El Ouirdi, A., Segers, J., \& Henderickx, E. (2014). Social media conceptualization and taxonomy: A Lasswellian framework. Journal of Creative Communications, 9(2), 107-126.

Papageorgiou, D.S. (2015). Employees' perspectives on social media internal communication platforms' use and its impact on affective commitment. A qualitative case study in the hospitality industry.

Papasolomou, I. \& Melanthiou, Y. (2012). Social media: Marketing public relations' new best friend. Journal of Promotion Management, 18(3), 319-328.

Park, H.S. \& Im, B.C. (2001). Test of causal model for the efficient of the servants knowledge in the local administration. Korean Policy Studies Review, 10(1), 111-135.

Parveen, F., Jaafar, N.I., \& Ainin, S. (2015). Social media usage and organizational performance: Reflections of Malaysian social media managers. Telematics and Informatics, 32(1), 67-78.

Parveen, F., Parveen, F., Jaafar, N.I., Jaafar, N.I., Ainin, S., \& Ainin, S. (2016). Social media’s impact on organizational performance and entrepreneurial orientation in organizations. Management Decision, 54(9), 2208-2234.

Ryu, S., Ho, S.H., \& Han, I. (2003). Knowledge sharing behavior of physicians in hospitals. Expert Systems with Applications, 25(1), 113-122.

Razmerita, L., Razmerita, L., Kirchner, K., Kirchner, K., Nielsen, P., \& Nielsen, P. (2016). What factors influence knowledge sharing in organizations? A social dilemma perspective of social media communication. Journal of Knowledge Management, 20(6), 1225-1246.

Sanders, N.R. (2007). An empirical study of the impact of e-business technologies on organizational collaboration and performance. Journal of Operations Management, 25(6), 1332-1347.

Shami, N.S., Nichols, J., \& Chen, J. (2014, April). Social media participation and performance at work: A longitudinal study. In Proceedings of the SIGCHI Conference on Human Factors in Computing Systems (pp. 115-118). ACM.

Shirky, C. (2008). Here comes everybody. New York: Penguin

Sigalaa, M. \& Chalkiti, K. (2015) Knowledge management, social media and employee creativity. International Journal of Hospitality Management, 45, 44-58.

Sofijanova, E., \& Zabijakin-Chatleska, V. (2013). High performance work practices and organizational performance: an analysis of the Macedonian food and beverage industry. Presented at XI International Scientific Conference "Management and Engineering '13" on 23-26 June 2013, Sozopol, Bulgaria.

Srivastava, A., Bartol, K.M., \& Locke, E.A. (2006). Empowering leadership in management teams: Effects on knowledge sharing, efficacy, and performance. Academy of Management Journal, 49(6), 1239-1251.

Steenkamp, M. \& Hyde-Clarke, N. (2014). The use of Facebook for political commentary in South Africa. Telematics and Informatics, 31(1), 91-97.

Stollak, M., Vandenberg, A.S., Felhofer, N., \& Sutherland, P. (2014). How social media is influencing the job search process. Journal of Management and Marketing Research, 15, 1-7. Retrieved from http://www.aabri.com/ manuscripts/141817.pdf (March 2018).

Tajudeen, F.P., Jaafar, N.I., \& Ainin, S. (2017). Understanding the impact of social media usage among organizations. Information \& Management.

Talley, J.L. (2011). Decision making in organizations, 1-24. Retreived from http://www.jltalley.com/presentations/ Decision\%20Making.pdf (January 2018).

Team FME. (2013). Effective communication (online).Retrieved from www.free-management-ebooks.com/dldebkpdf/fme-effective-communication.pdf (5 October 2017).

Themessl-Huber, M. (2014). Evaluation of the $\chi 2$ statistic and different fit-indices under misspecified number of factors in confirmatory factor analysis. Psychological Test and Assessment Modeling, 56(3), 219-36.

Trimi, S. \& Galanxhi, H. (2014). The impact of Enterprise 2.0 in organizations. Service Business, 8(3), 405-424.

Wamba, S. \& Carter, L. (2013). Twitter adoption and use by SMEs: An empirical study in system sciences (HISS). In Proceedings of 46th Hawaii International Conference on System Sciences (pp. 2052-2049).

Weekley, E. (1967). An etymological dictionary of modern English (Vol. 1). New York

Williams, L.J. \& Anderson, S.E. (1991). Job satisfaction and organizational commitment as predictors of organizational citizenship and in-role behaviors. Journal of management, 17(3), 601-617.

Wu, C.W. (2016). The performance impact of social media in the chain store industry. Journal of Business Research, $69(11), 5310-5316$.

Yesil, S. \& Dereli, S.F. (2013). An empirical investigation of the organizational justice, knowledge sharing and innovation capability. Procedia, Social and Behavioral Sciences, 75, 199-208. 